\title{
Ensuring the Financial Sustainability of Tourism Organizations: Problems and Solutions
}

\author{
Yunus Alamovich Toyirov \\ PhD Student, Tashkent State University of Economics, Uzbekistan \\ http://dx.doi.org/10.18415/ijmmu.v9i2.3551
}

\begin{abstract}
Preserving jobs and qualified professionals in the tourism sector, which has suffered and continues to suffer the most as a result of the negative impact of the coronavirus pandemic, is one of the most pressing issues today to maintain their income and financial stability. The article analyzes the experience of foreign and national level in the formation of financial protection mechanisms necessary for the smooth operation of tourism organizations in times of crisis and other emergencies. The article also reflects the financial sustainability indicators proposed by the author and their economic significance.
\end{abstract}

Keywords: Tourism Industry; Coronavirus Pandemic; Financial Stability; Financial Stability Indicators; Economic Norms; Established Norms

\section{Introduction}

In our opinion, the issue of maintaining tourism activity and its financial stability in the context of the introduction of strict quarantine measures to prevent the spread of coronavirus infection, as well as the implementation of measures to minimize or eliminate the negative impact of any emergencies leading to restriction of human movement are the most pressing among the existing problems.

Such consideration is, first of all, to maintain the activities of the tourism industry and related organizations, which include large investments of public organizations, financial institutions and private investors, to ensure the employment of its employees, in addition, the granting of "holidays" on bank loans, taxes and other mandatory payments, the provision of various benefits and preferences will be an "additional burden" on the state budget in emergencies to prevent the observed financial difficulties from becoming a systemic crisis factor. In this situation, the allocation of a significant part of the state budget to this area will lead to limited opportunities for the implementation of social projects and the financing of sectors specializing in the protection of human life and health.

Second, the COVID-19 pandemic and the subsequent sharp changes in the requirements for the organization of the tourism industry and related industries, the introduction of fundamentally new tools to bring the industry out of crisis, as well as the fact that the benefits and preferences introduced in accordance with the relevant regulations are temporary in nature, which in the near future is likely to 
expand the chances of resumption of industrial activity or deepen the crisis in the industry. In this case, the decisive factors are the current and long-term actions of the participants of the market of tourist services, as well as the content and essence of the decisions made by government agencies. Tourism market participants will need to fully understand that the successful development of a business ecosystem requires, first and foremost, the establishment and strengthening of relationships based on mutual cooperation and assistance. In our opinion, relying on the principles of competition in emergencies and crises weakens the market position of all participants. Government agencies will need to review mechanisms and tools to support the tourism industry and related industries. These mechanisms and tools, in our opinion, should cover two main areas: a) development of criteria and norms that will allow the tourism industry and related industries to overcome financial difficulties independently in a sufficiently long period of time (formation of financial security "airbag" in crises and emergencies); b) introduction of new methods (in particular, the inclusion of "unemployment insurance" services in the life insurance system) of social and financial protection of employees in crises and emergencies. The aforementioned and other measures would have prevented the emergence of dependency in the tourism industry and related industries based on the constant acquisition of privileges and preferences, as well as to prevent the transfer of part of the business to the shadow economy to increase profitability.

Based on the above, this article will address the following issues:

- analysis of the system of absolute and relative indicators used at the global and regional levels to monitor the financial sustainability of organizations in the tourism industry;

- development of a unified system of financial stability indicators that can be applied in the activities of tourism organizations based on the results of the analysis.

\section{Scientific Literatures Review}

COVID-19 in Central Asia: economic impact, prepared by the Organization for Economic Cooperation and Development. (Organization for Economic Co-operation and Development, OECD) in June 2020: "The COVID-19 pandemic required prompt action on to mitigate the economic consequences of the measures taken by the authorities to expand the capacity of the national health care system and prevent the spread of the pandemic, as well as the impact on consumption levels. The IMF forecasts that by 2020, global economic growth may slow to 3 percent. In the first quarter of 2020, the EU's gross domestic product fell by 3.5 percent. Policy measures should focus on supporting household income, the business environment, and key macroeconomic indicators that are important for rapid and effective recovery. While these measures will require a significant increase in state budget expenditures, the cost of inaction (destruction of production capacity in the long run) will be even higher [1].

In the scientific article of Russian scientists professor I.V.Taranova, associate professors Yu.O. Shavrina and V.I. Skrovatskaya on the topic "Methodological approaches to assessing the financial sustainability of service organizations in the region" noted: "In the context of the economic crisis, the goal of any business entity is to ensure financial stability for development while maintaining its activities in the future ...thus, It can be noted that a modern position defined as a set of indicators representing the adequacy of sources of working capital is being formed based on the classical concept expansion of financial stability with the analysis of private, debt capital and other relative indicators [2].

In the research work of GS Andreeva "Assessment of financial and economic stability of companies in the context of the development of the system of self-regulation" it was concluded that it is expedient to develop indicators for assessing the level of financial and economic stability by areas of activity [3]. These indicators are considered by the scientist grouped as: a) financial stability; b) 
production stability; c) investment stability; g) marketing stability; d) innovation sustainability; e) market (activity) stability; j) social stability; h) environmental sustainability; k) information stability.

In practice, models (including E. Altman's model) that determine the probability of occurrence of financial stability bankruptcy, multi-factor analysis (including U. Beaver's five-factor system) method, models aimed at determining the level of risk (including Value-at-Risk (VaR)), etc. are used.

Almost all of the methods mentioned above and suggested in other scientific and practical sources require a large amount of technical, informational and labor resources. The fact that the main part of the tourism industry operating in our country consists of small businesses and private entrepreneurs limits the possibility of full use of these models and methods. Thus, a system of unified financial stability indicators is required, which corresponds to the capabilities of the specified tourism industry entities, as well as can reflect the economic interests of the state (in terms of ensuring state budget revenues) and society (in terms of meeting the demand for quality and affordable tourist services).

\section{Research Methodology}

The theoretical and scientific-methodological basis of the research is the results of scientific research in the field of analysis of the current state of organizational and economic mechanisms of sustainable development of tourism and their improvement by domestic and foreign scientists and practitioners.

The research used statistical data on the topic, logical thinking, scientific observation, systematic approach, statistical and comparative analysis in the study of theoretical and methodological issues.

\section{Analysis and Results}

First of all, it should be noted that the concept of financial stability is interpreted differently in scientific sources. In particular, according to A.D. Sheremet, R.S.Sayfullin, financial stability is a condition of accounts that guarantees the solvency of the enterprise [4]. G.V. Savitskaya described financial stability as the ability to maintain a balance between assets and liabilities in a changing internal and external environment, the ability to operate and develop, the guarantee of investment attractiveness within the limits of solvency and permissible risk. [5]. According to B.A. Reisenberg, L.Sh. Lozovsky, E.B. Starodubtseva, financial stability is the level of risk of an enterprise in terms of balancing or increasing revenues relative to expenses [6].

Analysis of regulatory documents adopted in different countries The concept of "financial stability" is largely classified in relation to the activities of the banking system. In particular, the Banking Act of 2009 contains the concept of "financial stability objective" it is emphasized that ensuring financial stability is the main goal of the UK banking system [7]. Financial stability is achieved by reducing or eliminating the impact of systemic risks to protect and strengthen the UK financial system, as well as by supporting the Government's economic policies.

The essence of the concept of "financial stability" in US law is given in the introductory part of the Financial Stability Law (Financial Stability Act), adopted in 2010. [8]. Financial stability in the United States is ensured by improving the transparency and accountability of the financial system, overcoming the negative effects of "too big to fail," protecting American taxpayers and consumers, and using other means. 
The concept of "financial stability" in Swedish law is defined in the 2015 Swedish Banking Act (Sveriges Riksbank Act) by defining banking functions [9]. The Bank of Sweden ensures financial stability by guaranteeing protected and efficient payments. In addition, to ensure financial stability, the issuance of banknotes and coins, measures to prevent financial crises and other mechanisms will be used.

Based on the above and the analysis of the legislation of other countries, it can be concluded that "financial stability" at the national level is a set of measures aimed at increasing the state's tolerance to the negative effects of internal and external environment for sustainable development. Based on this interpretation, it can be concluded that the financial sustainability of tourism organizations is a set of measures aimed at creating the ability to independently eliminate any negative impacts that may occur in the internal and external environment.

We move on to the second direction of the assigned tasks. The Russian Federation is one of the countries that has taken significant measures to analyze the financial sustainability of business entities at the national level. Although there are significant differences between the methodologies developed and recommended in different government agencies of the country, it is of particular interest in terms of simplicity and compliance with the technical and communication capabilities available in almost all economic entities. In particular, it is recommended to use the methods set out in the normative documents below to eliminate the influence of subjective factors (any economic indicator can be interpreted differently by analysts within the requirements of the methodology used) on the amount of calculated indicators.

According to the methodological recommendations for the analysis of financial and economic activities of organizations, approved by the State Statistics Committee of Russia on November 28, 2002 [10], the analysis is carried out in the following areas:

- analysis of the organization's assets and sources of their formation. The analysis is carried out through: a) analysis of the structure of assets; b) analysis of the structural structure of the sources of asset formation; c) analysis of changes in assets and their sources. The analysis should allow to identify negative trends in the activities of organizations, such as absolute and relative decrease in the amount of cash, increase in debt to private funds, increase in short-term liabilities, increase in short-term loans over short-term payables, decrease in retained earnings;

- analysis of the solvency and financial stability of organizations. According to the methodology, the financial stability of the organization is classified by the state of financial resources, which allows to increase sales through the continuous expansion of production processes and increase profits. Solvency, on the other hand, determines the ability of an organization to make timely payments on its obligations. It is recommended to use 14 coefficients in the analysis. In turn, criteria are set for each coefficient. In particular, the ratio of debt to private funds should not be less than $100 \%$, the ratio of financial resources to the balance sheet currency of private funds and long-term liabilities should be in the range of 50-60\%;

- analysis of financial results of organizations, efficiency of use of assets and sources of their formation. In the process of analysis, it is assumed that the return on assets (groups), the profitability of sources (groups) of assets, the profitability of sales of goods, products, works and services. It should be noted that while profitability indicators, which measure the efficiency of net profit, are important for creditors and shareholders of the organization, for government agencies are important indicators of overall profitability, reflecting the relationship between the financial condition of the organization and budgeting;

- assess the financial condition of the organization. If the financial condition of the organization meets all the criteria and criteria set out in the document, it is considered excellent, good, satisfactory, failure to meet any criteria (liquid assets deficit, the presence of overdue liabilities, etc.) is considered 
unsatisfactory. Conclusions on sectors of the economy or regions of the country are formed by summarizing the financial condition of individual organizations.

According to the methodology approved by Resolutions 367 and 855 of the Government of the Russian Federation [10], the following coefficients are used to assess the financial condition of debts, grouped into three main groups:

1. Coefficients for classifying the debtor's solvency:

- absolute liquidity ratio;

- current liquidity ratio;

- indicator of satisfaction of the debtor's obligations;

- level of solvency on current liabilities.

2. Coefficients for classifying the financial stability of the debtor:

- coefficient of autonomy;

- Private working capital ratio;

- the share of overdue accounts payable in liabilities;

- the ratio of receivables to total assets.

3. Coefficients for classifying the debtor's business activity:

- return on assets;

- net profit margin.

Despite the fact that the economic standards defined in the above methodology play a significant role in the classification of financial stability of the economy, including the tourism industry, in our opinion, a number of problematic situations can be noted:

- first, the lack of an integral link between the economic norms cited in the normative documents and the criteria set for them in individual cases. In particular, the formula for calculating the current liquidity ratio in the methodology of the State Statistics Committee is as follows:

\section{Current liquidity ratio $=$ short-term assets $/$ short-term liabilities}

According to the methodology approved by Resolutions 367 and 855 of the Government of the Russian Federation:

\section{Current liquidity ratio $=$ liquid assets $/$ short-term liabilities}

In this case, liquid assets (cash, short-term financial investments minus the value of private shares purchased from shareholders) include highly liquid current assets, short-term receivables, other current assets. Current liabilities include loans and borrowings with a maturity of 12 months after the reporting 
period, accounts payable, income payable to the founders (to shareholders) and other short-term liabilities.

- secondly, the interpretation of the results obtained from the calculation of financial indicators, the periodicity of the analysis of the dynamics of indicators, the lack of clear recommendations for the assessment of negative or positive trends. In particular, one of the coefficients used in the methodology developed by the State Statistics Committee is the ratio of debt to capitalization, which is calculated as the ratio of long-term liabilities to the sum of private funds and long-term liabilities. According to the methodology, the increase in this indicator is a negative trend in the form of increasing dependence on external factors. However, it is not clear when the figure will increase. In our opinion, the increase in this indicator over a period of time is not always assessed as a negative trend. In particular, when an organization obtains an investment loan (lender's participation in the project should not be less than 20\%) from a commercial bank to expand production, the figure naturally increases and tends to decrease during the implementation of the project;

- third, the subject (s) of the analysis are not clearly identified. In particular, the "Methodological recommendations for the analysis of financial and economic activities of organizations" approved by the State Statistics Committee of Russia on November 28, 2002: "These methodological recommendations are intended for application in the practical activities of specialists engaged in the analysis of financial and economic activities of organizations". Whether the experts are the employees of the organization being analyzed or the auditors involved or others need to be clarified. Because only in this way can the analysis be determined by whom. In our opinion, all of the above methods are intended for external (remote or on-site) inspection (audit). We think, the analysis of the financial and economic activities of the organization should be carried out independently, and the results obtained should be evaluated by control entities.

\section{Conclusions and Suggestions}

The analysis of methodologies developed by a number of foreign countries and some organizations of our country allows to develop a system of indicators used to assess the level of financial sustainability of tourism organizations. In our opinion, this system of indicators can be grouped as follows:

1. Indicators of an organization's ability to control its own costs may include:

Control over the use of the salary fund = the cost of salary payments / net sales volume;

Administrative cost control $=$ current expenses $/$ net sales volume;

Property, plant and equipment control = depreciation / net realizable volume;

Control over the use of borrowed funds = interest expenses on borrowed funds / net sales volume;

Control over the formation of the price of the product $=$ recognition of the goods sold - price / net sales volume;

Control over the use of the tax system = tax payments $/$ net sales volume

2. It is expedient to assess the operational efficiency of the enterprise by the following indicators: 
value of goods sold during the year / commodity - the average volume of inventories (or turnover of inventories);

net sales volume / total assets;

net sales volume / fixed capital (funds).

3. The ability to sell products (services) can be assessed by the following indicators: sales;

gross profit margin $=($ net volume of sales - recognition of goods sold - price $) /$ net volume of

net profit margin = net amount of net profit / sales after taxes.

4. Liquidity indicators include the following:

current liquidity ratio $=$ current assets $/$ current liabilities;

net current assets $=$ current assets - inventories of raw materials, supplies or goods - current liabilities;

net working capital $($ capital $)=$ current assets - current liabilities.

5. The main indicators in the analysis of the level of financial leverage are as follows:

Leverage indicator $=$ total liabilities $/$ total assets

Capitalization indicator $=$ long-term debt obligations $/$ long-term debt obligations + capital

The ratio between debt and sales volume = total liabilities $/$ net sales volume

6. Off-balance sheet liabilities. Typically, an entity's balance sheet does not reflect a number of claims that may be made in the future. But they must be considered. Such applications may include:

warranties and guarantees;

warranties and guarantees under the enterprise's products;

legal proceedings against the enterprise;

other off-balance sheet liabilities.

The results of the analysis show that ensuring the financial sustainability of enterprises in the tourism industry serves to strengthen the ability to protect independently from negative processes in the internal and external environment. The planning of measures to be taken to increase the level of financial stability should be based on the results of an in-depth study of the enterprise. The use of the proposed system of indicators in the study during the study:

- First, the submission of financial statements to tax, statistical and other regulatory authorities through an automated system in Microsoft Excel allows you to perform all calculations on the basis of the simplest programs. This is within the technical and technological capabilities available to all enterprises of the tourism industry; 
- Secondly, the system of indicators (due to the limited scope of scientific work, some of the calculations and conclusions were not presented) allows to draw conclusions in all areas of the enterprise;

- Thirdly, it allows you to quickly identify the strengths and weaknesses of the enterprise during remote or on-site inspections (audits). It also plays a role in the development of a number of enterprise development programs.

\section{References}

1. Organization for Economic Co-operation and Development (OECD). "COVID-19 in Central Asia: Consequences and Policy Measures". June 2020 https://www.oecd.org/

2. Moscow Economic Journal. 2020 №4 https:/qje.su/wp-content/uploads/2020/04/Nomer-4-2020Arhiv.pdf 636-645 стр.

3. G.S.Andreeva. Assessment of the financial and economic stability of companies in the context of the development of the self-regulation system. diss. 08.00.10 - Finance, money circulation and credit. St. Petersburg, 2018

4. Sheremet A. D. Saifulin R. S. Negashev E. V. Methods of financial analysis. Tutorial.M. Infra-M. 2001 208 pages

5. Savitskaya GV Analysis of economic activity of the enterprise. Proc. Benefit. 5th ed., revised. and additional - M. New knowledge: 2009. p 536.

6. Raizberg B.A., Lozovsky L.Sh., Starodubtseva E.B. Modern economic dictionary. 6th ed., revised. and additional - M: INFRA-M, 2011

7. United Kingdom. Law on Banks (Banking http://www.legislation.gov.uk/ukpga/2009/1/section/238

8. United States. Financial Stability Law (Financial Stability Act) http://www.cfr.org/unitedstates/restoring-american-financial-stability-act-2010-s-3217/p22715

9. Sweden. Swedish Riksbank Law (Sveriges Riksbank Act) http://www.riksbank.se/en/TheRiksbank/Legislation/The-Sveriges-Riksbank-Act

10. Legislative base of the Russian Federation https://zakonbase.ru/

\section{Copyrights}

Copyright for this article is retained by the author(s), with first publication rights granted to the journal.

This is an open-access article distributed under the terms and conditions of the Creative Commons Attribution license (http://creativecommons.org/licenses/by/4.0/). 